\title{
The Production of Secondary Metabolites by Plant Cells Cultivated in Bioreactors ${ }^{1}$
}

\author{
Wolfgang Kreis ${ }^{2,3}$ and Ernst Reinhard ${ }^{2}$ \\ ${ }^{1}$ Presented as a Plenary Lecture at the "International Conference on Plant Science and its Relevance to the Future", Delhi, India, \\ March 1988 \\ ${ }^{2}$ Pharmaceutical Institute, University of Tübingen, D-7400 Tübingen, Federal Republic of Germany \\ ${ }^{3}$ Address for correspondence
}

Received: November 10, 1988

Alant cell cultures are a potential source of
Abstract
pharmaceutically important plant metabolites. In the past
few years a lot of success has been achieved in the field of the
cultivation of plant cells on a large scale. Special bioreactor
systems, such as airlift or drum-type fermentors have been
devised for the mass cultivation of plant cells. Classical stir-
red-tank bioreactors (up to 75000 l volume) have also been
used for the cultivation of plant cells and the production of
important plant metabolites. Plant cells proliferate much
slower than microbial cells. In consequence, the time taken
to grow a plant cell suspension from the shake-flask level
(300 ml) to the production scale (20,000 l) takes about 3 to 6
weeks. Nevertheless, the cost analyses available show that
the production of valuable chemicals by a suitable plant cell
culture process could be commercially viable. Plant cells
have been grown in batch and repeated batch culture, and
single- stage as well as two-stage processes have been de-
veloped for the production of secondary metabolites by fer-
mentor-cultured plant cells. There are, however, only few
cell culture processes that have attracted industrial atten-
tion as yet. Biological rather than technological problems
are the main obstacles to a more common use of fermentor-
cultured plant cells in industry.

\section{Introduction}

Higher plants provide us with a large variety of valuable natural products such as flavors, insecticides, and pharmaceuticals. Despite remarkable advances in synthetic organic chemistry, plants are still the sole source of about $25 \%$ of prescribed medicines (1). Since it is generally possible to cultivate plant cells in large quantities under aseptic conditions, plant cell suspension cultures are regarded as potentially suitable systems for producing phytochemicals of high economic value $(2,3,4)$.
Studies on the production of plant secondary metabolites by plant cell suspension cultures have been comprehensively described $(5,6)$. Several plant cell cultures have been shown to produce large amounts of secondary metabolites (Table 1a), but although the number of high-yielding cell cultures increases yearly, there are still plant species which fail to produce their important natural products when cultivated in the form of an undifferentiated cell culture $(7,8,9$; Table $1 \mathrm{~b})$. Many of these recalcitrant plant species provide us with very important natural products, such as codeine, quinine, tropane alkaloids, or cardiac glycosides.

Table 1 Plant cell cultures and their potential for producing plant secondary products.

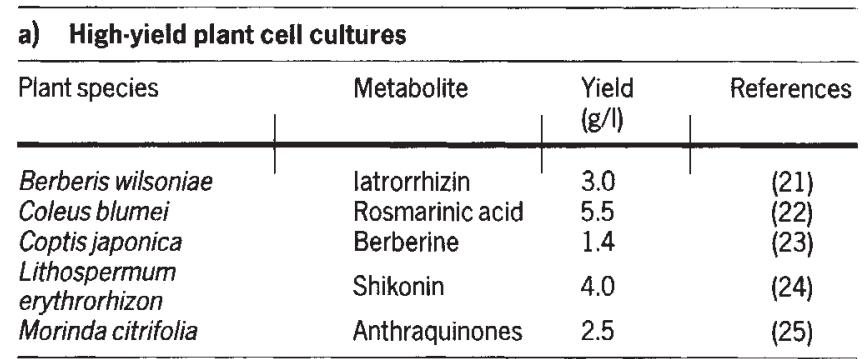

b) Recalcitrant plant cell cultures

\begin{tabular}{|c|c|c|}
\hline Plant species & Metabolite & References \\
\hline $\begin{array}{l}\text { Atropa belladonna } \\
\text { Cinchona ledgeriana } \\
\text { Digitalis lanata } \\
\text { Duboisia leichhardtii } \\
\text { Papaver somniferum } \\
\text { Rauwolfia serpentina }\end{array}$ & $\begin{array}{l}\text { Atropine } \\
\text { Quinine } \\
\text { Digoxin } \\
\text { Hyoscine } \\
\text { Codeine } \\
\text { Reserpine }\end{array}$ & $\begin{array}{l}(26,27) \\
(28,29,30) \\
(31,32,33) \\
(34) \\
(35,36,37) \\
(38)\end{array}$ \\
\hline
\end{tabular}

c) Plant cell cultures that produce secondary metabolites hitherto not known to occur in the intact plant

\begin{tabular}{lllll} 
& Metabolite & Class & References \\
\hline Plant species & Andrographis paniculata & Paniculides & Sesquiterpenes & $(39)$ \\
Gardeniajasminoides & Tarennosid & Monoterpene & $(40)$ \\
Morinda citrifolia & 5,6 -Dihydroxy- & Anthraquinone & $(41)$ \\
& lucidin & & \\
Ochrosia elliptica & Epchrosine & Indole alkaloid & $(42)$ \\
Picralima nitida & Pericine & Indole alkaloid & $(43)$ \\
Ruta graveolens & Rutacultin & Furanocoumarin & $(44)$ \\
Stephania cepharantha & Armorine & Alkaloid & $(45)$ \\
Thuja occidentalis & Hinokiol & Diterpene & $(46)$ \\
\hline
\end{tabular}


Some cell cultures produce secondary metabolites not yet known to occur in the respective mother plants $(5,9,10$; Table 1c). This has prompted some research groups to screen plant cell cultures for novel, pharmacologically active principles. Many plants produce biologically active compounds but cannot be grown on a large scale. Here, plant suspensions cultures are receiving much attention and are used in the production of these compounds (e.g. 11).

It is beyond the scope of this paper to review the basic problems of how to establish high-yielding cell cultures (see references $12,13,14$ ), how to deal with the problem of the instability of high-producing cell lines (see references 15 , 16,17 ), and how to improve the cells' productivity (see references $18,19,20$ ). We shall focus instead on advances made recently in the field of the large-scale cultivation of plant cells and the production of biologically active plant metabolites by fermentor-cultured plant cells.

\section{Large-Scale Cultivation and Economic Considerations}

In 1959, Tulecke and Nickell (47) were the first to report on the large-scale cultivation of plant cells. During these early studies steel tanks with volumes of up to 134 litres were already used. In the past few years, quite a lot of success has been achieved in the field of the fermentation and scale-up of cell suspensions. Plant cells are now cultivated in volumes of up to 75,000 litres (92), specific fermentor systems for plant cells have been developed, and productive cell culture systems have been established. (For recent reviews on mass culture systems for plant cells refer to $48,49,50,51$.)

Although plant cell cultures are regarded as an alternative to the agricultural production of natural products, biotechnological processes with plant cells are expected to be more costly than any of the microbial processes established so far, despite all the advances made in cell culture technology. Thus, chemicals which are candidates for production by plant cell cultures have to be of high economic value.

The most detailed cost analysis was produced by Goldstein et al. (52). Their analyses give a good account of the different aspects that have to be considered in evaluating the cost of a plant cell culture process. Assuming that a conventional microbial fermentor is used to cultivate the plant cells, and that $10,000 \mathrm{~kg}$ of a fine chemical are produced per year, Goldstein and co-workers calculated a break-even against running costs if the product's selling price is US $\$ 1368$ per kilogram. Other authors estimated the minimum selling prices more optimistically (17) or more pessimistically (3) (Table 2 ). Yet, all the calculations available demonstrate that the produc-

Table 2 Evaluations of the profitability of plant cell culture processes.

\begin{tabular}{|c|c|c|c|c|c|}
\hline \multirow{2}{*}{$\begin{array}{l}\text { Vessel } \\
\text { size } \\
\left(\mathrm{m}^{3}\right)\end{array}$} & \multicolumn{3}{|c|}{ Production } & \multirow{2}{*}{$\begin{array}{c}\text { Break-even } \\
\text { product } \\
\text { price } \\
\text { (US } \$ / \mathrm{kg})\end{array}$} & \multirow{2}{*}{ Reference } \\
\hline & $\begin{array}{l}\text { Produc- } \\
\text { tivity } \\
(g / \mid)\end{array}$ & $\begin{array}{l}\text { Yield } \\
\text { (kg/a) }\end{array}$ & $\begin{array}{l}\text { Cycle } \\
\text { (d) }\end{array}$ & & \\
\hline $\begin{array}{r}100 \\
50 \\
50\end{array}$ & $\begin{array}{l}1.00 \\
\overline{0.25}\end{array}$ & $\begin{array}{r}- \\
10000 \\
375\end{array}$ & $\begin{array}{l}15 \\
- \\
10\end{array}$ & $\begin{array}{r}500 \\
1,368 \\
30,000\end{array}$ & $\begin{array}{l}(17) \\
(52) \\
(3)\end{array}$ \\
\hline
\end{tabular}

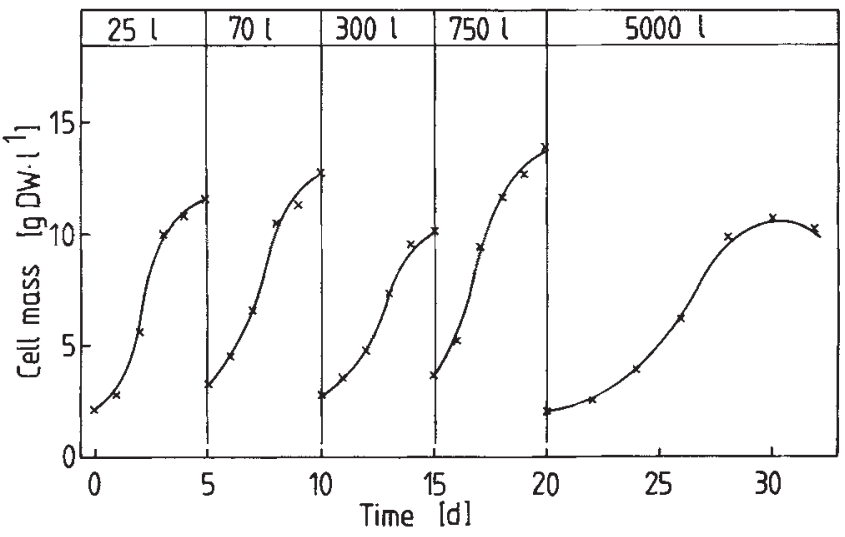

Fig. 1 Growth of Catharanthus roseus cells during scale-up from 25 to 5000 litres (modified after reference 58).

tion of valuable chemicals by a suitable plant cell culture process could be commercially viable.

Some properties of suspension-cultured plant cells have to be taken into consideration when we talk in terms of their cultivation on a large scale. Plant cells are much larger than microbial cells. In addition, only few plant cell cultures are real single cell cultures. Most often, plant cell suspensions consist of small aggregates of up to 200 cells each. Since metabolic activity is a function of an organism's surface, it is evident that growth rates are much lower in the case of plant cell cultures compared to microbial cells. For a well-growing plant cell suspension, doubling times are in the range of 15 to some $120 \mathrm{~h}$ (Table 3). As a consequence, the "preproduction phase", i.e. the time taken to grow the plant cells to the production scale is very time-consuming and may thus account for a significant part of the total cost of a biotechnological process. Usually, it takes about 20 to 40 days to establish a large-scale volume (Fig. 1). As a consequence, utmost attention has to be given to sterility during the scale-up, sample-taking, and production cycle. In the respective publications, no one reports on the ratio of overall fermentor runs to sterile runs. Hence, it is difficult to give objective figures, but from our own experiences we know that during repeated batch culture, infections can be avoided over long periods of time ( 3 months) and that less than $10 \%$ of fermentations run in the batch mode will get infected.

\section{Airlift Versus Stirred-Tank Bioreactors}

Suitable bioreactors (Fig. 2) for plant cells had to be developed, since the cellulose cell walls seem to be quite sensitive to the high shear forces that are known to occur in microbial fermentation systems (stirred-tank bioreactors). One approach to the problem was the introduction of airlift bioreactors, where stirrers could be omitted. In 1977, Wagner and Vogelmann (59) reported on their investigations into the influence of different types of bioreactors on natural product synthesis. They already recognized that the low productivities achieved in reactors with turbine impellers resulted mainly from agitation problems. They explained their findings as a result of an oxygen limitation in stagnant zones together with mechanical damage to the cells in the turbulent region. From their results the authors concluded that the airlift system is superior to the stirred-tank system. The use of airlift bioreactors to cultivate 


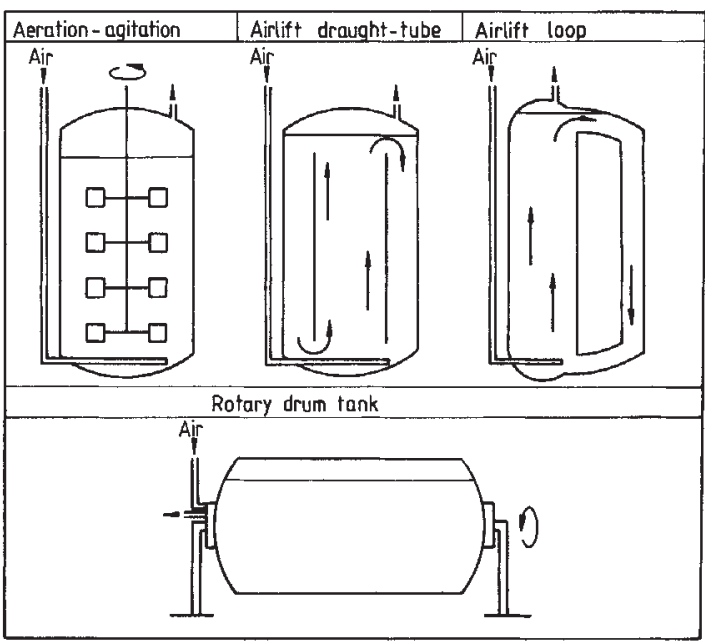

Fig. 2 Bioreactors used for the cultivation of plant cells on a large scale.

plant cells on a large scale has also been studied extensively by Fowler and co-workers (3).

It was found that the airlift bioreactors turned out to be problematic at high biomass levels. Here, efficient mixing and sufficient oxygen supply are not always guaranteed. In addition, the high aeration rates necessary cause trouble due to vigorous foaming. Therefore, stirrers have been invented which can be used to mix plant cell cultures grown in bioreactors.

Tanaka (62), for example, has cultured $\mathrm{Mac}$ lura tricupidata cells in bioreactors equipped with several types of stirrers (Fig. 3). In these studies the best results were obtained when a paddle impeller was used to mix the plant cells. Ulbrich (53) compared various agitation modes in standard vessels and found that rosmarinic acid production with $\mathrm{Col}$ -

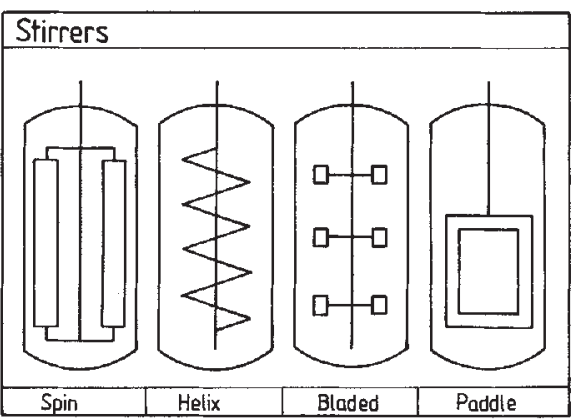

Fig. 3 Bioreactors equipped with various stirrers.

eus blumei cells was best $(3.3 \mathrm{~g} / 1)$ when a helical stirrer, termed "module spiral stirrer" was used.

Cardenolide biotransformation, which will be reviewed in more detail later on, was improved when performed in stirred-tank reactors. When Digitalis lanata cells were cultivated in a 20 -litre airlift bioreactor, $653 \mathrm{mg} \beta$-methyldigitoxin per litre were produced after 20 days of cultivation. If, on the other hand, stirrer-equipped bioreactors of similar size were used productivity increased, and $720 \mathrm{mg} / 1$ (helical stirrer) or $776 \mathrm{mg} / \mathrm{l}$ (spin stirrer) were produced (63).

It was reported that oxygen tension in the culture medium influences alkaloid production by cultured plant cells $(23,64)$. In the case of selected Berberis wilsoniae (Berberidaceae) cell cultures (65), which are known to produce high amounts of protoberberine alkaloids, such as iatrorrhizine and berberine, the influence of dissolved oxygen on protoberberine production was investigated in more detail (60). Maximum alkaloid production was achieved at dissolved oxygen levels of $50 \%$. After 20 days of cultivation in a 20 -litre airlift bioreactor about $3 \mathrm{~g}$ alkaloids per litre were produced, representing more than $10 \%$ of the cells' dry weight. At still higher aeration rates

\section{a) Comparison of cell sizes, surfaces, and volumes}

\begin{tabular}{lcc|c}
\hline Species & Size $(\mu \mathrm{m})$ & Surface $\left(\mu \mathrm{m}^{2}\right)$ & Volume $\left(\mu \mathrm{m}^{3}\right)$ \\
\hline Serratiamarescens & $0.5 \times 1.7$ & 6.9 & 1.3 \\
Escherichia coli & $1.3 \times 4.0$ & 43 & 21 \\
Bacillus megaterium & $1.2 \times 7.6$ & 66 & 34 \\
Saccharomyces cerevisiae & 3.5 (sphere) & 153 & 179 \\
Coleus blumei & 60.0 (sphere) & 4500 & 900,000 \\
\hline
\end{tabular}

\section{b) Comparison of growth rates}

\begin{tabular}{lccc}
\hline Species & $\begin{array}{c}\text { Doubling } \\
\text { Time }(h)^{\mathrm{a}}\end{array}$ & $\begin{array}{l}\text { Specific Growth } \\
\text { Rate }(1 / \mathrm{h})\end{array}$ & References \\
\hline Escherichia coli & 0.33 & 2.1 & $(54)$ \\
Nicotiana tabacum & 15 & 0.046 & $(55)$ \\
Malus communis & 31.5 & 0.022 & $(56)$ \\
Morinda citrifolia & 45 & 0.015 & $(57)$ \\
Coleus blumei $_{\text {Catharanthus roseus }}$ & 53 & 0.013 & $(58)$ \\
Berberis wilsoniae $^{\mathrm{b}}$ & 72 & 0.010 & $(59)$ \\
Digitalis lanata $^{\mathrm{c}}$ & 100 & 0.007 & $(60)$ \\
\hline
\end{tabular}

\footnotetext{
a For the most part calculated from growth curves.

b Cultivated in a 20 litre airlift bioreactor.
}

c Cultivated in a 300 litre airlift bioreactor.
Table 3 Eucaryotic and procaryotic cells in culture (modified after reference 53 ). 


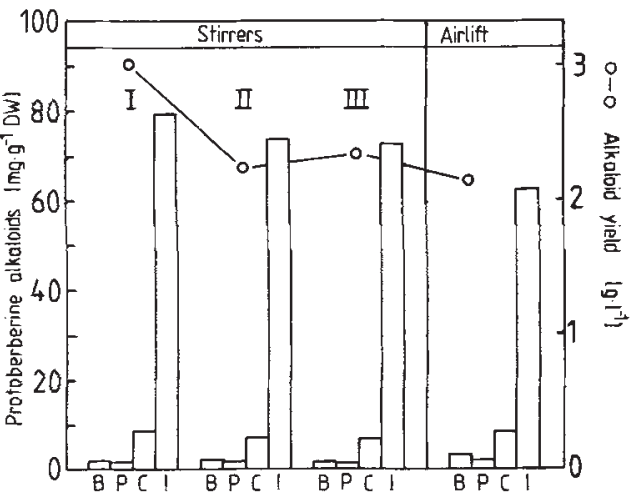

Fig. 4A

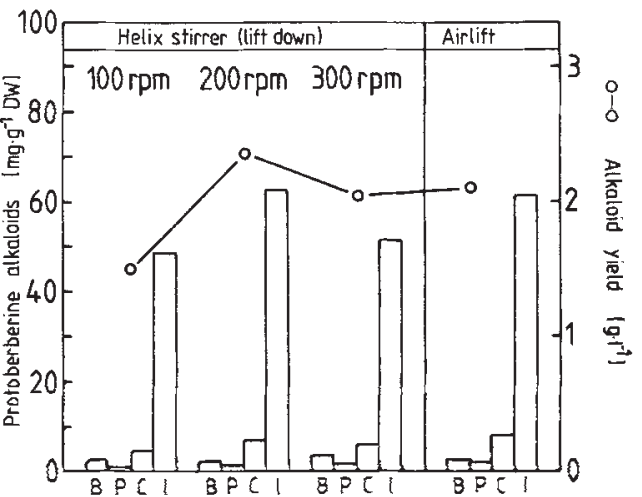

Fig. 4B

Fig. 4 A. Influence of stirrer velocity on alkaloid production. Berberis wilsoniae cells were cultivated in a Biostat $U 30 \mathrm{D}$ bioreactor equipped with a helical stirrer (lift down mode). B. Influence of stirrer type on alkaloid production. 1. Flat blade turbine (bladed stirrer) with baffles, II. Flat blade turbine without baffles, III. Module spiral stirrer (helical stirrer) lift mode. $B=$ berberine, $\mathrm{I}$ = iatrorrhizine, $\mathrm{C}=$ columbamine, $\mathrm{P}=$ palmatine.

(60\% dissolved oxygen), productivity decreased and only $1 \mathrm{~g}$ alkaloids per litre medium was produced.

Using a Biostat U 30 D bioreactor (Braun Co. Melsungen, FRG), the influence on alkaloid production of stirrer type, stirrer velocity, and dissolved oxygen (DO) level was examined. Due to the plant cells' sensitivity to high shear forces, it is generally advisable to use low stirrer velocities (about 50 to $200 \mathrm{rpm}$, depending on the stirrer type used).

With the stirrer velocity set to $100 \mathrm{rpm}$, alkaloid production was clearly demonstrated to depend on the oxygen available in the medium. At a DO level of $20 \%$, about $1.0 \mathrm{~g}$ protoberberines per litre were produced. If the level of DO was raised to $40 \%$, productivity increased to some $1.4 \mathrm{~g}$ per litre. The alkaloid production could be further increased (to $2.4 \mathrm{~g} / \mathrm{l})$ if the helical stirrer was run at $200 \mathrm{rpm}$. This was mainly due to the far better growth of the cells as compared to their growth at $100 \mathrm{rpm}$. Still higher stirrer velocities resulted in a reduced cell growth and hence reduced productivity (Fig. 4A).

Several stirrer types (spin stirrer, bladed stirrer, helical stirrer, see Fig. 3) were tested and it was found that maximum alkaloid production is achieved if a bladed stirrer is used together with baffles (Fig. 4B). In this case the level of alkaloids at the end of a fermentation run was as high as in the respective experiments where airlift bioreactors were used. Using either fermentor system, a productivity of $150 \mathrm{mg} / /^{*} \mathrm{~d}$ could be achieved.

It is thus seen that plant cells may be cultivated in canventional stirred-tank bioreactors, although at present no guidelines can be given concerning the best stirrer type. Depending on the cell culture used in each of the respective investigations, high growth rates as well as good production rates were achieved with either spin stirrers (63), helical stirrers (53), or bladed stirrers (60).

Only recently, a novel fermentation mode was introduced by Fujita and Tabata (2). They designed a rotary drum-type tank (Fig. 2) and compared the production of shikonin by Lithospermum erythrorhizon cells cultivated in conventional bioreactors with the productivity obtained in drum-type reactors of equal size. The authors found that, during scale-up to 1000 litres, productivity decreased when the stirred-tank mode was used. Using rotary drum tanks, on the other hand, they were able to scale up the volume to 1000 litres with no decrease in shikonin yield.

\section{Batch Culture and Repeated Batch Culture}

Although many plant cell cultures fail to synthesize secondary metabolites, they might be of some biotechnological importance due to their ability to perform specifíc chemical reactions ("biotransformations"). Like microbial processes, biotransformation reactions might be used in biotechnological processes with plant cells (66).

In this context, we should refer to the successful cardenolide biotransformation with Digitalis lanata (Scrophulariaceae) cell cultures (67). A semisynthetic cardenolide, $\beta$-methyldigitoxin, is $12 \beta$-hydroxylated by selected cell lines to $\beta$-methyldigoxin with good yields and almost no side reaction (68). After a series of experiments with Digitalis cells cultivated in reactor vessels of various size, this biotransformation process could be further improved with regard to medium composition and the manner in which the substrate is fed to the cultured cells (61). Finally, Digitalis lanata cell suspensions were scaled up to 210 litres. The $12 \beta$-hydroxylation of $\beta$-methyldigitoxin to $\beta$-methyldigoxin was performed in a 300 litre airlift bioreactor, yielding about $100 \mathrm{~g} \beta$-methyldigoxin after 18 to 20 days of fermentation (69).

On the basis of our experiences in scaling up Digitalis lanata cells from the $300-\mathrm{ml}$ level to the 300 -litre bicreactor, we estimate that establishing an industrial scale volume of about 20,000 litres would last some 40 days. Only after that propagation phase can the biotransformation process be initiated. With a view to circumventing these rather long non-producing phases, semi-continuous fermentation systems were investigated. The fermentation mode used for the production of $\beta$-methyldigoxin is the "repeated batch culture", where most of a given fermentor-cultured suspension is harvested from the stationary phase of the growth cycle. The bioreactor is then refilled with fresh medium after which the next production cycle can be initiated. In this way, a process was developed in which $513 \mathrm{~g}$ of $\beta$-methyldigoxin were produced after 89 days of fermentation in a 300 -litre airlift reactor (61). 


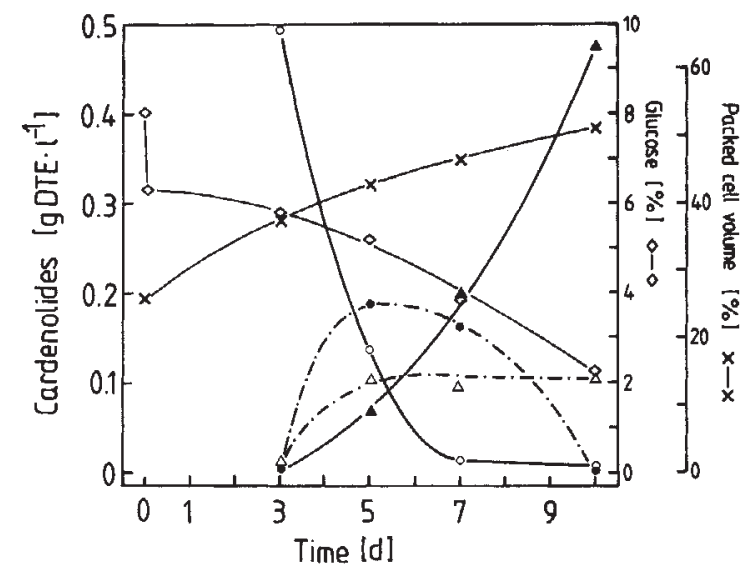

Fig. 5 Formation of deacetyllanatoside $C$ in a 20-litre airlift bioreactor. Digitoxin (O-O), purpurea-glycoside $A(\triangle-\Delta)$, digoxin (- $)$, deacetyllanatoside $\mathrm{C}(\mathbf{\Delta}-\mathbf{\Delta})$.

\section{Two-Stage Culture}

The two-stage concept, where cells are proliferated in a growth medium and metabolite synthesis is achieved in a suitable production medium, takes into account the fact that fast-growing cells often are low-yielding ones. This phenomenon has been observed for many cell cultures, and two-stage culture may hence be regarded as a standard approach towards the establishment of productive cell culture processes (93).

The two-stage concept was applied in an alternative approach using the biotransformation potential of $D i$ gitalis lanata cells. This process takes advantage of the cells' specific storage capacity for primary cardiac glycosides (70, 71). The primary glycoside of interest is deacetyllanatoside $C$, the production of which involves two bioconversion steps, namely $12 \beta$-hydroxylation and $16^{\prime}-O$-glucosylation of digitoxin.

Digitalis cells were propagated in a growth medium and then transferred into production medium. Under optimum conditions all of the substrate added was biotransformed after 12 days of incubation, yielding the main product deacetyllanatoside C (88\%) together with purpureaglycoside $A$, both of which accumulated in the cells $(72,73)$.

This process was successfully transferred to the 20-litre scale (airlift bioreactor) where $13.2 \mathrm{~g}$ deacetyllanatoside $\mathrm{C}$ and $1.1 \mathrm{~g}$ purpureaglycoside $\mathrm{A}$ were produced from $11.7 \mathrm{~g}$ digitoxin after 9 days of incubation (94) (Fig. 5).

The first commercial product derived from plant cell culture is obtained from cultured Lithospermum erythrorhizon cells. Shikonin, which is produced in the roots of Lithospermum erythrorhizon (Boraginaceae) is mainly used in Japan for treating injuries, burns, and haemorrhoids, and as a traditional silk dye. It takes about 4 years until Lithospermum plants can be harvested for shikonin isolation. The chemical synthesis of shikonin has been reported, but since it took 12 reaction steps with a final yield of just $0.7 \%$, chemical synthesis is not economical at the present time (24).

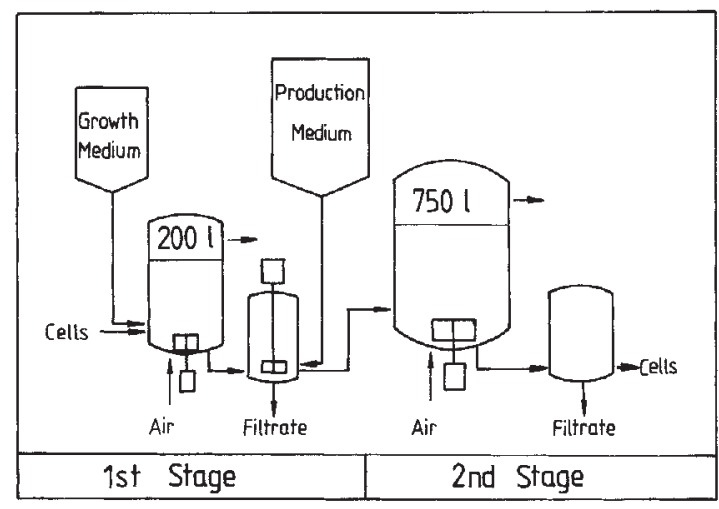

Fig. 6 Flow-chart of two-stage fermentation of Lithospermum erythrorhizon cells (after reference 24).

In Japan, the Mitsui Petrochemical Industries have succeeded in establishing a two-stage fermentation process for the production of shikonin with suspension-cultured Lithospermum erythrorhizon cells $(74,75)$. The cells are proliferated in a propagation medium using a 200-litre stirred-tank bioreactor as the culture vessel. Under these conditions the cells fail to synthesize shikonin derivatives. When a sufficient cell mass is produced the cells are inoculated, together with a suitable production medium (76), into a 750-litre bioreactor (Fig. 6). After 14 days of culture in the production medium the cells are harvested and the red pigment is extracted from the cultured cells.

One single run in a 750-litre fermentor yields as much shikonin as $176,400 \mathrm{~m}^{2}$ fields of cultivated Lithospermum erythrorhizon plants, and it was estimated that production of shikonin using cell cultures is about 800 times more efficient than with field-grown plants (24). Shikonin produced by cultured Lithospermum cells has been used for cosmetics in Japan since 1984.

A model process yielding the highest reported production rates is the production of rosmarinic acid by Coleus blumei (Lamiaceae) cells. In 1977, rosmarinic acid was first isolated form cultured Coleus blumei cells $(77,78)$. Then, the cellculture group of the A. Nattermann Company (Köln, FRG) developed a process for the production of rosmarinic acid on a large scale using Coleus blumei suspension cultures. It served mainly as a model system for process optimization in the field of plant cell culture technology. Detailed investigations into the culture medium composition and its influence on cell growth and product accumulation resulted in the formulation of two different media, which were found conducive to either good cell growth or rosmarinic acid production. A two-stage process was developed, in the first stage of which Coleus blumei cells are grown in a 42-litre airlift bioreactor (working volume 32 litres). When the appropriate cell density is reached, about $30-50 \%$ of the suspension are inoculated into a stirred-tank bioreactor (working volume 32 litres). Using this two-stage procedure, as much as $5.5 \mathrm{~g}$ rosmarinic acid, representing $21 \%$ of the cells' dry weight, were produced per litre suspension after 6 days of cultivating the Coleus cells in the production medium (Fig. 7). 


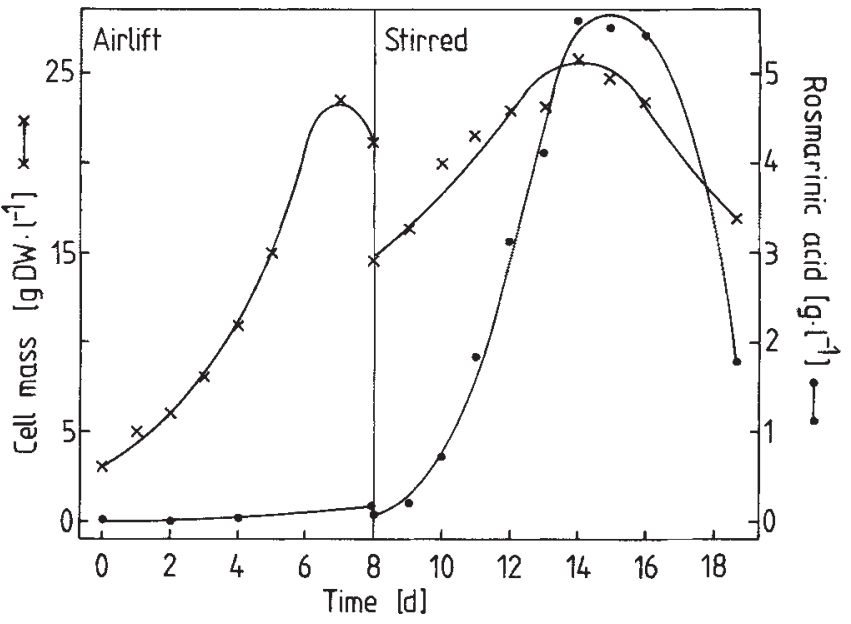

Fig. 7 Two-stage process of rosmarinic acid production by Coleus blumei cells (modified after reference 22).

In the meantime, Coleus blumei cells were cultivated in a 200-litre airlift bioreactor (140 litres working volume), where rosmarinic acid reached $12 \%$ of the cells' dry weight at the end of the production cycle (79).

\section{Morphological Differentiation as a Prerequisite for Product Accumulation}

One characteristic feature of all organisms is that certain biochemical traits are only fully developed in specific organs or during specific developmental stages. This holds true in great measure for higher plants, where development, morphological differentiation, and secondary metabolism are closely connected. It has been reported repeatedly that undifferentiated plant cell tissues, which do not produce a certain metabolite, recover their synthetic capacity during morphogenesis. This makes it clear that we must correct the assumption that cell cultures, if to be used in bioreactor processes, have to be fine suspensions consisting of very small cell aggregates or even single cells.

Coleus forskohlii (Lamiaceae) forms a series of labdanes (80). One of these is forskolin, a compound which is known to stimulate adenylate cyclase, leading to an increase in cellular c-AMP level $(81,82)$. Forskolin is usually produced by extraction from the roots of Coleus forskohlii plants.

Fine cell suspension cultures established from different Coleus forskohlii plants were unable to produce forskolin under the medium conditions necessary for optimum growth and viability. However, by changing the phytohormone balance in the medium, morphogenesis could be induced (83) and it was found that cell aggregates forming small roots produced considerable amounts of forskolin $(83,84)$. The cultivation conditions were optimized with regard to medium composition and root induction period, and finally a product yield of about $1 \mathrm{~g} / \mathrm{kg}$ dry weight was achieved in experiments on the shake flask level.

The whole process was then scaled up to the 20-litre airlift fermentor. Cells were cultivated for $14 \mathrm{~d}$ under root-inducing conditions and were then transferred into the bioreactor. The plant tissue produced and accumulated forskolin from days 5 through 15, after which production and cell growth ceased. By the end of the fermentor run $134.3 \mathrm{mg}$ of forskolin were produced, accumulating in the tissue in concentrations of about $730 \mathrm{mg} / \mathrm{kg}$ dry weight (85). Finally, Coleus forskohlii suspension cultures were scaled up to a 300-litre bioreactor and at the end of a 17-day fermentation run about $325 \mathrm{mg}$ of forskolin were produced.

\section{Perspectives}

There is no doubt that plant cell cultures are a potential source of important secondary metabolites. We are now at a stage where most of the technical problems concerning the cultivation of plant cells on a large scale are solved. However, there are only very few cell culture processes, that have attracted industrial attention as yet. The main obstacle to a more common use of fermentor-cultured plant cells in industrial processes are biological problems and some of them will be described briefly.

The most severe problem is that it cannot be predicted whether the cells of a given plant species will produce the compound of interest when cultivated in vitro. Strangely enough, the very plant metabolites which are of the highest economic interest cannot yet be produced by plant cell cultures. Here, basic research is necessary concerning the enzymes involved in biosynthetic pathways and the regulation of these enzymes on both the physiological and genetic level. Molecular biology techniques have to be employed in investigations into the biochemistry of natural product synthesis. It has to be stressed that, in addition to the actual biosynthetic steps, other processes like product degradation, transport, and storage play important roles during the accumulation of plant secondary metabolites, and hence have to be elucidated on the enzymatic and molecular level. Only after detailed investigations, not just with model systems but with the plant species of economic interest itself, can that "black box", the cultured plant cell, be fully explored.

It was stressed that in the case of suspensioncultured Coleus forkohlii cells, forskolin production was only achieved with morphogenic, root-forming clumps (85). Similar results were obtained in studies performed by Luckner and coworkers (for a review, see 32), who demonstrated that embryogenic cell clumps of Digitalis lanata can be cultivated in airlift bioreactors where they produce up to $1.5 \mathrm{mg}$ cardenolides per litre.

Using these two examples, Coleus and Digitalis, we can describe another important problem. The Coleus clumps produce a metabolite pattern very similar to that of the Coleus forskohlii root, and hence a biotechnological process using fermentor-cultured Coleus clumps may be substituted for the field-grown plant. Embryogenic cultures of $D i$ gitalis, however, only synthesize cardenolides not used in therapy (86). Besides the fact, then, that productivity would have to be improved by a factor of 100 to 1000 before cardenolides can be produced economically, the main shortcoming of the Digitalis embryoid structures is that they produce the "wrong" cardenolides.

Only recently, a series of reports indicated the potential of Agrobacterium rhizogenes-transformed cells for 
producing secondary metabolites (e.g. $87,88,89$ ). In these cases morphogenesis, namely the formation of hairy roots, was a result of the incorporation of a piece of the microbe's DNA into the genome of the plant cell. In the biosynthesis of natural products normally produced in the roots of plants, this approach may yield a suitable culture material for the production of secondary metabolites in bioreactors.

While we are talking in terms of the genetic manipulation of plant cells, we should briefly discuss the potential of genetic engineering with regard to its application to recalcitrant cell cultures. Berlin (9) emphasized that enzymes connecting primary and secondary pathways may play important regulatory roles in the biosynthesis of natural products. It is therefore necessary to isolate these enzymes from the appropriate source and characterize them. Investigations on the molecular level into the expression of the respective enzyme in both the synthesizing tissue and the non-productive cell culture have to follow. As a result a strategy for overcoming the problem of non-producing cell cultures can be developed using the genetic engineering toolbox. Since plant genes may be under the control of promotors regulated by developmental factors, one important step would be the construction of chimaeric genes (90) composed of constitutive promotors of viral or bacterial origin and the plant gene(s) responsible for the formation of the respective enzyme. The gene construction would then have to be introduced by means of a suitable vector, such as the Ti-plasmid (91), into a non-producing cell culture, and its expression, i.e. enzyme synthesis, would have to be confirmed.

\section{Conclusions}

The production of shikonin by Mitsui Petrochem. Ltd shows that plant cell culture has advanced beyond a mere academic tool. The basic problems of cultivating plant cells on a large scale have been solved, but now we find ourselves in need of new insights into the fundamental question of how to manipulate natural product biosynthesis in cultured plant cells. This challenge has to be met by the scientist, whose concern is the future use of plant cell cultures as a source of plant secondary metabolites.

\section{References}

1 Farnsworth, N. R., Morris, R. W. (1976) Am. J. Pharmacy 148, 4652.

2 Fujita, Y., Tabata, M. (1987) in: Plant biology, Vol. 3. Plant tissue and cell culture (Green, C. E., Somers, D. A., Hackett, W. P., Biesboer, D. D., eds.), pp. 169-185, Alan R. Liss Inc., New York.

3 Fowler, M. W. (1983) in: Plant biotechnology. Society for experimental biology seminar series; 18 (Mantell, S. H., Smith, H., eds.), pp. 337. Cambridge University Press, Cambridge, London, New York, New Rochelle, Melbourne, Sidney.

${ }^{4}$ Curtin, M. E. (1983) Biotechnology 1, 49-57.

${ }^{5}$ Nickell, L. G. (1980) in: Plant tissue culture as a source of biochemicals (Staba, E. J., ed.), pp. 256-259, CRC Press, Boca Raton.

${ }^{6}$ Misawa, M. (1985) in: Advances in biochemical engineering/ biotechnology 31. Plant cell culture (Fiechter, A., ed.), pp. 59-88, Springer-Verlag, Berlin, Heidelberg, New York, Tokyo.

7 Czygan, F.-C. (1984) in: Biogene Arzneistoffe (Czygan, F.-C., ed.), pp. 85-105, Friedr. Vieweg \& Sohn, Braunschweig. Wiesbaden.

${ }^{8}$ Fowler, M. W. (1985) in: Primary and secondary metabolism of plant cell cultures (Neumann, K. H., Barz, W., Reinhard, E., eds.), pp. 362370 , Springer-Verlag, Berlin, Heidelberg, New York, Toronto.

9 Berlin, J. (1984) Endeavour 8, 5-8.

10 Ruyter, C. M., Stöckigt, J. (1989) GIT Fachz. Lab. 33, 283-293.

11 Kesslring, K. (1985) in: Pflanzliche Zellkulturen (BMFT-Statusseminar), pp. 111-129, Bundesministerium für Forschung und Technologie, Bonn

12 Tahata, M., Ogino, T., Yoshioka, K., Yoshikawa, N., Hiraoka, N. (1978) in: Frontiers of plant tissue culture 1978 (Thorpe, T. A., ed.), pp. 213-222, Proc. 4th Intl. Congr. Plant Tissue Cell Culture, Univ. Calgary.

13 Widholm, J. M. (1980) in: Plant tissue culture as a source of biochemicals (Staba, E. J., ed.), pp. 99-114, CRC Press, Boca Raton.

14 Berlin, J., Sasse, F. (1985) in: Advances in biochemical engineering/ biotechnology 31. Plant cell culture (Fiechter, A., ed.), pp. 99-132, Springer-Verlag, Berlin, Heidelberg, New York, Tokyo.

15 Deus-Neumann, B., Zenk, M. H. (1984) Planta Med. 50, 427-431.

16 Seitz, U. (1987) Planta Med. 53, 311-314.

17 Zenk, M. H. (1978) in: Frontiers of plant tissue culture 1978 (Thorpe, T. A., ed.), pp. 1-13, Proc. 4th Intl. Assoc. Plant Tissue Culture, Univ. Calgary.

18 Constabel, F., Eilert, U. (1986) IAPTC Newsletter 50, 3-8.

19 Mantell, S. H., Smith, H. (1983) in: Plant biotechnology. Society for experimental biology seminar series; 18 (Mantell, S. H., Smith, H., eds.), pp. 75-100, Cambridge University Press, Cambridge, London, New York, New Rochelle, Melbourne, Sidney.

${ }^{20}$ Lindsey, K., Yeoman, M. M. (1983) in: Plant biotechnology. Society for experimental biology seminar series; 18 (Mantell, S. H., Smith, H., eds.), pp. 39-66, Cambridge University Press, Cambridge, London, New York, New Rochelle, Melbourne, Sidney.

21 Breuling, M., Alfermann, A. W., Reinhard, E. (1985) Plant Cell Reports $4,220-223$.

22 Ulbrich, B., Wiesner, W., Arens, H. (1985) in: Primary and secondary metabolism of plant cell cultures (Neumann, K.-H., Barz, W., Reinhard, E., eds.), pp. 293-303, Springer-Verlag, Berlin, Heidelberg, New York, Toronto.

23 Sato, F., Yamada, Y. (1984) Phytochemistry 23, 281-285.

24 Tabata, M., Fujita, Y. (1985) in: Biotechnology in plant science (Day, P., Zaitlin, M., Hollander, A., eds.), pp. 207-218, Academic Press, Florida.

25 Zenk, M. H., El-Shagi, H., Schulte, U. (1975) Planta Med. Suppl. $1975,79-101$

26 Hashimoto, T., Sato, F., Mino, M., Yamada, Y. (1982) in: Plant tissue culture. Proc. 5th Int. Congr. Plant Tissue Culture (Fujiwara, A., ed.), pp. 305-306, Jap. Assoc. Plant Tissue Culture, Tokyo.

27 Czygan, F.-C. (1975) Planta Med. Suppl. 1975, 169-185.

28 Staba, E. J., Chung, A. C. (1981) Phytochemistry 20, 2495-2498.

29 Verpoorte, R., Wijnsma, R., Mulder-Krieger, T., Harkes, P. A. A., Baerheim-Svendsen, A. (1985) in: Primary and secondary metabolism of plant cell cultures (Neumann, K.-H., Barz, W., Reinhard, E., eds.), pp. 196-208, Springer-Verlag, Berlin, Heidelberg, New York, Toronto.

${ }^{30}$ Robins, R. J., Payne, J., Rhodes, M. J. C. (1986) Planta Med. $220-$ 226. 
${ }^{31}$ Kartnig, T. (1977) in: Plant tissue culture and its biotechnological application (Barz, W., Reinhard, E., Zenk, M. H., eds.), pp. 44-51, Springer-Verlag, Berlin, Heidelberg, New York.

32 Luckner, M., Diettrich, B. (1985) in: Plant tissue culture and its biotechnological application (Barz, W., Reinhard, E., Zenk, M. H., eds.), pp. 154-163, Springer-Verlag, Berlin, Heidelberg, New York.

${ }^{33}$ Ohlssen, A. B., Björk, L., Gatenbeck, S. (1983) Phytochemistry 22, $2447-2450$.

${ }^{34}$ Yamada, Y., Endo, T. (1982) Plant Cell Reports 3, 186-188.

35 Tam, W. H., Constabel, F., Kurz, W. G. (1980) Phytochemistry 19, $486-487$.

36 Lockwood, G. B. (1984) Z. Pflanzenphysiol. 114, 361-363.

37 Heinstein, P. F. (1985) J. Nat. Prod. 48, 1 -9.

${ }^{38}$ Yamamoto, O., Yamada, Y. (1986) Plant Cell Reports 5, 50-53.

${ }^{39}$ Butcher, D. N., Connoly, J. D. (1971) J. Exp. Bot. 22, 314-322.

40 Ueda, S., Kobayashi, K., Muramatsu, T., Inouye, H. (1981) Planta Med. 41, 186-191.

41 Inoue, K., Nayeshiro, H., Inouye, H. Zenk, M. (1981) Phytochemistry 20, 1693-1700.

42 Pawelka, K.-H., Stöckigt, J. (1985) Z. Naturforsch. 41c, 381-384.

43 Arens, H., Borbe, H. O., Ulbrich, B., Stöckigt, J. (1982) Planta Med. $46,210-214$

44 Steck, W., Bailey, K. B., Shyluk, J. P., Gamborg, O. L. (1971) Phytochemistry 10, 191-194.

45 Akasu, M., Itokawa, H., Fujita, M. (1972) Phytochemistry 11, $3041-$ 3043.

46 Berlin, J. (1983) Chemie unserer Zeit 17, 77-84.

47 Tulecke, W., Nickell, L. G. (1959) Science 130, 863-865.

48 Fowler, M. W. (1982) Progress in Industrial Microb. 17, 207-229.

49 Martin, S. M. (1980) in: Plant tissue culture as a source of biochemicals (Staba, E. H., ed.), pp. 143-160, CRC Press, Boca Raton.

50 Lee, J. M., An, G. (1986) Enzyme Microb. Technol. 8, 260-265.

51 Fowler, J. M. (1987) in: Plant biology, Vol. 3. Plant tissue and cell culture (Green, C. E., Somers, D. A., Hackett, W. P., Biesboer, D. D., eds.), pp. 458-471, Alan R. Liss Inc., New York.

${ }^{52}$ Goldstein, W. E., Ingle, M. B., Lasure, L. (1980) in: Plant tissue culture as a source of biochemicals (Staba, E. J., ed.), pp. 191-234, CRC Press, Boca Raton.

${ }^{53}$ Ulbrich, B. (1986) in: Proceedings of the 7th conference on global impacts of applied microbiology. Symposia on alcohol fermentation and plant cell culture (Kohola, M., Tuompo, H., Kauppinnen, V., eds.), pp. 147-164, Foundation for biotechnological and industrial fermentation research 4 , Helsinki.

${ }^{54}$ Schlegel, H. G. (1975) Allgemeine Mikrobiologie, 4th ed., p. 173.

55 Noguchi, M., Matsumoto, T., Hirata, Y., Katsuyama, A., Kato, A., Azechi, S., Kato, K. (1977) in: Plant tissue culture and its biotechnological application (Barz, W., Reinhard, E., Zenk, M, H., eds.), pp. 85-94, Springer-Verlag, Berlin, Heidelberg, New York.

56 Pareilleux, A., Chaubet, N. (1980) Biotech. Lett. 2, 291-296.

57 Schulte, U. (1978) Thesis, University of Bochum.

${ }^{58}$ Schiel, O, Berlin, J. (1987) Plant Cell Tissue Organ Cult. 8, 153-161.

59 Wagner, F., Vogelmann, H. (1977) in: Plant tissue culture and its biotechnological application (Barz, W., Reinhard, E., Zenk, M. H., eds.), pp. 245-252, Springer-Verlag, Berlin, Heidelberg, New York.

60 Breuling, M. (1986) Thesis, University of Tübingen.

61 Reinhard, E., Kreis, W., Barthlen, U., Helmbold, U. (1989) Biotech. Bioengin., in the press.

62 Tanaka, H. (1982) Biotech, Bioengin. 24, 425-442

${ }^{63}$ Spieler, H. (1985) Thesis, University of Tübingen.

64 Yamada, Y., Sato, F. (1981) Phytochemistry 20, 545-547.

${ }^{65}$ Rothenberger, S. (1982) Thesis, University of Tübingen.

${ }^{66}$ Reinhard, E., Alfermann, A. W. (1980) in: Advances in biochemical engineering 16. Plant cell culture (Fiechter, A., ed.), pp. 49-83, Springer-Verlag, Berlin, Heidelberg, New York.

${ }^{67}$ Reinhard, E., Boy, M., Kaiser, F. (1975) Planta Med. Suppl. 1975, $163-168$.

68 Heins, M. (1978) in: Production of natural compounds by cell culture methods (Alfermann, A. W., Reinhard, E., eds.), pp. 39-46, Ges. Strahlen- und Umweltforsch., München.

69 Alfermann, A. W., Bergmann, W., Figur, C., Helbold, U., Schwantag, D., Schuller, I., Reinhard, E. (1983) in: Plant biotechnology. Society for experimental biology seminar series; 18 (Mantell, S. H., Smith, H., eds.), pp. 67-74, Cambridge University Press, Cambridge, London, New York, New Rochelle, Melbourne, Sindey.

${ }^{70}$ Kreis, W., Reinhard, E. (1985) Pharmazeut. Zeitung 130, 23152316.
${ }^{71}$ Kreis, W., Reinhard, E. (1987) J. Plant. Physiol. 128, 311-326.

72 Kreis, W., Reinhard, E. (1986) Planta Med, 418-419.

${ }^{73}$ Kreis, W., Reinhard, E. (1988) Planta Med. 54, 143-148.

74 Mitsui Petrochem. Ind. Ltd. (1982) Ipn. Patent I 57039-778.

${ }^{75}$ Mitsui Petrochem. Ind. Ltd. (1982) Jpn. Patent J 57039-779.

76 Fujita, Y., Tabata, M., Nishi, A., Yamada, Y. (1982) in: Plant tissue culture. Proc. 5th Int. Congr. Plant Tissue Culture (Fujiwara, A., ed.), pp. 399-400, Jap. Assoc. Plant Tissue Culture.

77 Zenk, M. H., El-Shagi, H. E., Ulbrich, B. (1977) Naturwissenschaften $64,585$.

${ }^{78}$ Razzaque, A., Ellis, B. E. (1977) Planta 137, 287-291.

79 Ulbrich, B., Alfermann, A. W., Reinhard, E., unpublished results.

80 Bhat, S. V., Bajwa, B. S., Dornauer, H., De Souza, N. J. (1977) Tetrahedron Lett. 1669-1972.

81 Metzger, H., Lindner, E. (1981) Arzneimittel-Forsch./Drug Res. 31, $1248-1250$.

${ }^{82}$ Seamon, K. B., Daly, J. W. (1981) J. Cyclic Nucl. Res. 7, $201-224$.

83 Mandler-Henger, A. (1988) Thesis, University of Tübingen.

84 Mersinger, R. (1988) Thesis, University of Tübingen.

${ }^{85}$ Mersinger, R., Dornauer, H., Reinhard, E. (1988) Planta Med. 54, 200-203.

86 Seidel, S., Reinhard, E. (1987) Planta Med. 53, 308-309.

87 Mano, Y., Nabeshima, S., Matsui, C., Ohkawa, H. (1986) Agric. Biol. Chem. 50, 2715-2722.

88 Hamill, J. D., Parr, A. J., Robins, R. J., Rhodes, M. J. C. (1986) Plant Cell Reports 5, 111-114.

89 Yoshikawa, T., Furuya, T. (1987) Plant Cell Reports 6, 449-453.

${ }^{90}$ SteinbiB, H. H., Schell, J. (1987) Z. Naturforsch. 42c, 1011-1018.

91 Schröder, J., De Greve, H., Hernalsteens, J. P., Leemans, J., Van Montagu, M., Otten, L., Schröder, G., Willmitzer, L., Schell, J. (1983) in: Plant biotechnology. Society for experimental biology seminar series; 18 (Mantell, S. H., Smith, H., eds.), pp. 313-326, Cambridge University Press, Cambridge, London, New York, New Rochelle, Melbourne, Sidney.

92 Wagner, H., Stuppner, H., Puhlmann, J., Brümmer, B., Deppe, K., Zenk, M. H. (1989) Z. Phytotherapie 10, 35-38.

93 Zenk, M. H., El-Shagi, H., Arens, H., Stöckigt, J., Weiler, E. W., Deus, B. (1977) in: Plant tissue culture and its bio-technological application, (Barz, W., Reinhard, E., Zenk, M. H., eds.), pp. 27-43, Springer-Verlag, Berlin.

94 Kreis, W., Zhu, W., Reinhard, E. (1989) Biotechnol. Lett. 11, 325330. 